GLOBAL DEVELOPMENT AND ENVIRONMENT INSTITUTE

WORKING PAPER No. 03-05

\title{
Economic Reform, Energy, and Development: The Case of Mexican Manufacturing
}

Francisco Aguayo and Kevin P. Gallagher

July 2003

Tufts University

Medford, MA 02155, USA

http://ase.tufts.edu/gdae 


\title{
Economic Reform, Energy, and Development: The Case of Mexican Manufacturing
}

\author{
Francisco Aguayo and Kevin P. Gallagher \\ faguayo@colmex.mx,kevin.gallagher@tufts.edu
}

\begin{abstract}
Given increasing concern over global climate change and national security there is a burgeoning interest in examining the relationship between economic growth and energy use in developed and developing countries. More specifically, delinking energy use per unit of gross domestic product (GDP) has fast come to be seen as in the interests of national economies and the world as a whole. Recent attention has been paid to the dramatic decreases in the energy intensity of the Chinese economy, which fell by 55 percent between 1975 and 1995 (Sinton and Fridley, 2000). Do other developing economies follow similar trajectories?

This paper examines the energy intensity of the Mexican economy for the period 1988 to 1998. Although the long-term trend in Mexican energy intensity is rising, the energy intensity of the Mexican economy began to decline in 1988. This paper delineates the factors that have contributed to these reductions.

Diminishing Mexican energy use per unit of GDP has been driven by significant decreases in industrial energy intensity. We show that these changes are due to changes in the composition of Mexican industrial structure, and technological change.
\end{abstract}




\section{Introduction}

The paper is organized into six parts. After a short introduction to energy use in Mexico, there is a description of the data used for our analysis. Third, we explain general trends in the energy intensity of Mexican industry. Fourth, we present a methodology and analysis to explain the changes in energy intensity identified in section three. In the fifth section we examine specific changes in five key industries. The last section summarizes our finding and offers lessons for sustainable development.

Mexico is one of the more energy intensive economies in the world. When measured in energy use per dollar in purchasing power parity terms for comparison purposes, its energy intensity is 8.7 megajoules per U.S. dollar. The United States, Japan, the European Union, and China are slightly more energy intensive, each country consumes approximately 10 megajoules per dollar. In the past twenty years, each of these latter countries has seen a rapid decline in energy to GDP ratios, in large part due to 20 to 50 percent declines in ratios for the industrial sector (WEA, 2001).

Table 1. Energy use and energy intensity growth.

\begin{tabular}{|c|c|c|c|c|c|c|c|}
\hline & Total & $\begin{array}{l}\text { Primary } \\
\text { comsumption }\end{array}$ & $\begin{array}{l}\text { Industry and } \\
\text { Mining /2 }\end{array}$ & Residential & Transport & Agriculture & $\begin{array}{l}\text { Non-energetic final } \\
\text { consumption }\end{array}$ \\
\hline Share of total energy use (\%) /1 & 100 & 31.7 & 21.3 & 14.1 & 24.8 & 1.8 & 6.3 \\
\hline Growth in intensity $1965-1988$ & 25.0 & -39.7 & 14.3 & -23.9 & 38.0 & -11.8 & 20.5 \\
\hline Growth in intensity $1988-1998$ & -10.3 & -0.1 & -15.7 & -4.3 & 2.3 & -25.6 & -11.2 \\
\hline
\end{tabular}

Source: Authors' calculations based on Indicadores del Sector Energético, Secretaría de Energía, and National Account System, INEGI.

Notes: 1/ Average share for the period 1988-1998

2/ Includes manufacturing industries, mining and construction, but excludes oil and gas extracting 
Figure 1. Energy Intensity of the Mexican Economy

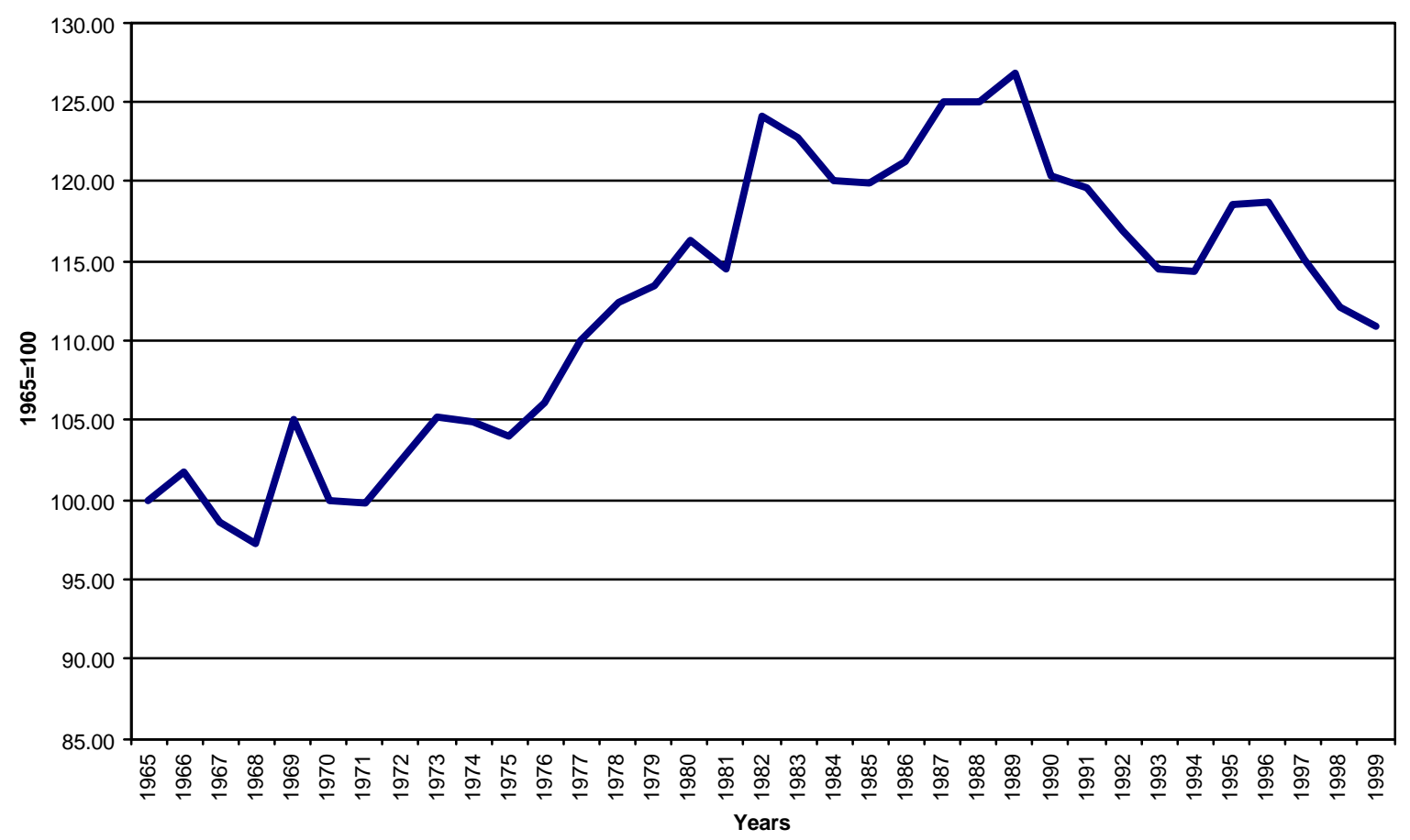

Source: National Accounts System, INEGI; Secretaría de Energía. Dirección General de Política y Desarrollo Enérgeticos

Mexico has not followed the trends of the OECD countries. Figure 1 shows megajoules of energy per unit of GDP in Mexico from 1965 to 1999 (in thousands of 1980 pesos). Energy intensity has grown by 10 percent during this period. These increases have been caused mostly the increased oil production in Mexico, and by a 14 percent increase in industrial energy intensity. As this figure shows however, there are signs of change toward the end of the 1980s. As shown in Table 1, between 1988 and 1998, the energy intensity of the Mexican economy fell by more than 10 percent.

Also shown in Table 1, the reductions are driven by a 15.7 percent decline in energy intensity in the mining and industrial sectors (referred to as industrial sector throughout the rest of the paper). During this period, the industrial share of total energy use in Mexico was just over 20 percent, making it the third largest user of energy in Mexico. In value-added terms, it is the largest energy consumer in Mexico. The rest of this paper asks: what is driving these decreases in the energy intensity of Mexican industry? 


\section{Data}

To perform our analyses we rely on three major data sources in Mexico: the National Energy Balance, the National Account System, and the Industrial Census.

Energy data comes from the National Energy Balance (NEB), the most comprehensive energy database in Mexico. Published annually, the NEB has provided comprehensive coverage of energy activity since 1965. Energy figures in the NEB are expressed in joules ${ }^{1}$.

Value added data comes from the National Account System and in some cases from the Industrial Census. Regarding the National Accounts, the Mexican statistical agency, INEGI, changed the base year in the early 90's, interrupting the continuity of value added series. The first, longer series uses 1980 as its base year and extends from 1965 to 1993. The second series has 1993 as a base year and covers the 1988 to 1998 period. Therefore, in order to construct a coherent time series from 1965 to 1999, we had to adjust value added figures for the 1989 period 1999 to the 1980 base series. We did this by taking the last figure for 1988 from the 1980 base series, and the annual growth rates from the 1993 base series. This exercise was only necessary for presenting the energy intensity of the Mexican economy from 1965 to 1999 in Figure 1 and is consistent with other methods and graphs. For the more specific exercises pertaining to Mexican industry from 1988 to 1998, we use actual value added figures from the 1993 base National Account System.

Figures regarding the number of establishments, labor-productivity and other economic indicators for specific branches of industry that are presented at the end of the paper are from Mexico's Industrial Census.

\section{Trends in the Energy Intensity of Mexican Industry}

To analyze the trends in industrial energy use we rely on the standard measure of energy intensity (see columns 2 and 3 in Table 2). Energy intensity for every manufacturing branch (i) at any year (t) is calculated as the ratio of energy consumption per unit of value added:

$$
e_{i t}=\frac{c_{i t}}{v a_{i t}}
$$

\footnotetext{
${ }^{1}$ By law ("Ley Federal sobre Metrología y Normalización") the joule is the compulsory, legal instrument to measure energy and heat in Mexico (Balance Nacional de Energía 1999, p. 14)
} 
Table 2: Energy intensity of Mexican Manufacturing, 1988 to 1998

(intensities in megajoules per $\$ 10001993$ pesos)

\begin{tabular}{|c|c|c|c|c|c|c|c|c|}
\hline & $\frac{\text { Average energy use }}{\underline{1988-1998 \%}}$ & Inten: & & $\frac{\text { Intensity }}{\text { change (\%) }}$ & Comp & ition & $\frac{\text { Weighted Intensity }}{(\text { WI })}$ & $\frac{\text { Composition of WI }}{\text { Change }}$ \\
\hline & & $\underline{1988}$ & 1998 & & 1988 & $\underline{1998}$ & change & \\
\hline & (1) & (2) & (3) & (4) & (5) & (6) & (7) & (8) \\
\hline Total & 100.0 & $4,312.8$ & $3,659.9$ & -15.1 & $4,312.8$ & $3,659.9$ & -652.8 & 100.0 \\
\hline Iron and steel & 17.8 & $36,861.8$ & $23,523.1$ & -36.2 & 907.3 & 688.5 & -218.9 & 33.5 \\
\hline Chemicals & 10.1 & $4,469.9$ & $4,219.3$ & -5.6 & 409.0 & 390.8 & -18.2 & 2.8 \\
\hline Sugar & 10.4 & $67,622.1$ & $54,562.7$ & -19.3 & 513.0 & 379.2 & -133.8 & 20.5 \\
\hline Petrochemicals (] & 14.5 & $104,564.5$ & $83,395.8$ & -20.2 & 820.6 & 401.1 & -419.5 & 64.3 \\
\hline Cement & 8.4 & $26,056.8$ & $22,809.7$ & -12.5 & 387.8 & 287.4 & -100.4 & 15.4 \\
\hline Mining & 4.8 & $2,809.8$ & $3,659.4$ & 30.2 & 179.6 & 190.9 & 11.3 & -1.7 \\
\hline Pulp and paper & 4.1 & $12,402.1$ & $8,059.9$ & -35.0 & 194.1 & 128.8 & -65.3 & 10.0 \\
\hline Glass & 2.6 & $10,484.5$ & $7,098.3$ & -32.3 & 119.3 & 92.4 & -27.0 & 4.1 \\
\hline Beer and malt & 1.0 & $2,981.7$ & $2,745.9$ & -7.9 & 40.9 & 42.5 & 1.6 & -0.2 \\
\hline Fertilizers & 1.1 & $19,581.3$ & $22,616.3$ & 15.5 & 51.5 & 30.3 & -21.2 & 3.2 \\
\hline Automotive & 0.6 & 307.2 & 249.9 & -18.7 & 20.0 & 24.7 & 4.7 & -0.7 \\
\hline Beverages & 0.6 & 766.8 & $1,104.1$ & 44.0 & 16.3 & 24.5 & 8.2 & -1.3 \\
\hline Construction & 0.5 & 84.1 & 115.3 & 37.1 & 15.4 & 18.4 & 3.0 & -0.5 \\
\hline Rubber & 0.4 & $2,278.3$ & $2,179.0$ & -4.4 & 18.7 & 16.7 & -2.0 & 0.3 \\
\hline Aluminium & 0.4 & $11,855.7$ & $6,977.2$ & -41.1 & 24.4 & 15.2 & -9.2 & 1.4 \\
\hline Tobacco & 0.0 & 199.3 & 229.2 & 15.0 & 1.7 & 1.6 & -0.2 & 0.0 \\
\hline Other branches & 22.7 & $1,094.7$ & $1,713.3$ & 56.5 & 593.0 & 927.1 & 334.1 & -51.2 \\
\hline
\end{tabular}

Source: National Accounts System, INEGI; Secretaría de Energía. Dirección General de Política y Desarrollo Energeticos.

Table 2 exhibits the trends in energy intensity for a number of individual industry and mining branches between 1988 and 1998. The largest energy consumer in this sector is iron and steel, which consumes almost 18 percent of the total. In terms of energy intensity, it is third behind the petrochemicals and the sugar industries. Of the most energy intensive industries, significant reductions occurred in iron and steel (36 percent), pulp and paper (35 percent), petrochemicals (19 percent), and cement (12 percent). These five consume 55 percent of all energy in industry and mining. The only energy intensive branch that saw an increase in energy intensity was mining, where intensity increased by 30 percent. 
Put simply, this analysis calculates the energy use in each sector per unit of total value added in the industry and mining sectors. Table 2 also examines the extent to which these levels change from 1988 to 1998, and in the last column expresses these changes in weighted intensity in percentage terms. If we define $\mathrm{C}$ as total manufacturing energy consumption and VA as total manufacturing value added, we have that energy intensity for the whole sector (E) can be decomposed as the summatory of the intensities of every branch weighted by its share in manufacturing value added:

$$
E_{t}=\frac{C_{t}}{V A_{t}}=\sum_{i=1}^{n} \frac{c_{i t}}{v a_{i t}}=\sum_{i=1}^{n}\left(\frac{c_{i t}}{v a_{i t}} * \frac{v a_{i t}}{\sum v a_{i t}}\right)=\sum_{i=1}^{n} e_{i t} s_{i t}
$$

where sit is the value added share of manufacturing value added and

$$
e_{i t}^{w}=e_{i t} s_{i t}
$$

is the weighted intensity for branch i. The composition of energy intensity for 1988 and 1998 is shown in Table 2 (columns 5 and 6). Hence, the change of total energy intensity within a period can be accounted for by the compositional changes, that is, the changes in the weighted intensities:

$$
E_{t}-E_{t_{o}}=\sum e_{i t}^{w}-e_{i t_{o}}^{w}
$$

where $t$ and to are the final and initial year, respectively (column 8, Table 2).

From this perspective, the following five sectors emerge as the most significant industries where reductions have occurred: petrochemicals, iron and steel, sugar, cement, and pulp and paper. Interestingly, these reductions offset a 51 percent increase in the relative energy use in "other branches", the more fabrication intensive industries.

To what extent are these changes in these five industries a function of their decline in value added terms or a function of technological changes within the industries themselves? The following section develops a methodology to address this question.

\section{Explaining Relative Effects of Compositional and Technology-based Change}

It is important to understand whether changes in energy intensity are due to compositional changes in the mix of energy intensive industries in an economy, from actual changes in technological changes within industries. To separate these effects, we draw on standard methodologies from energy and regional economics.

The methodology for delineating the relative difference between structural and technological change in industry has become quite standard. Indeed, previous 
work to this end has been done for Mexico. Thomas Sterner (1985) examined structural change and technology in Mexican manufacturing over the period 1970 to 1981 - period of falling energy prices in Mexico. Using fuel use data rather than energy intensity, Sterner measured compositional change as the weighted sum of the effects of industrial branch on fuel use while holding a base year (1970) constant. For technology, he calculated the weighted sum of the changes in energy intensity while holding the composition structure of the base year constant. Sterner's analysis was an attempt to explain why energy intensity increased over the period 1970 to 1981. Interestingly, he found that the composition effect was relatively unchanged over the period, but technology choice was causing increases in energy intensity because heavy energy using firms where adopting more energy using technologies. A similar method was used to separate changes in industry relative to other parts of the OECD economies (UNDP, 2001). We adopt Sterner's approach and analyze energy intensity over the period 1988 to 1998 . We also add a third, "mixed effect", by assessing the change in weighted intensity for every individual branch as the result of three effects:

$e_{i t}^{w}-e_{i t_{o}}^{w}=e_{i t} s_{i t}-e_{i t_{0}} s_{i t_{0}}=e_{i t}\left(s_{i t}-s_{i t_{0}}\right)+s_{i t_{0}}\left(e_{i t}-e_{i t_{0}}\right)+\left(e_{i t} e_{i t_{0}}\right)\left(s_{i t} s_{i t_{0}}\right)$

where

$e_{i t}\left(s_{i t}-s_{i t_{0}}\right)=$ compositio $\mathrm{n}$ effect

$s_{i t_{0}}\left(e_{i t}-e_{i t_{0}}\right)=$ intensity effect

$\left(e_{i t} e_{i t_{0}}\right)\left(s_{i t} s_{i t_{0}}\right)=$ mixed effect

This method also adapts the basic concept of "shift and share" tools, used in regional economics, although this is not a direct application (see Richardson, 1978). The composition effect captures the change in weighted intensity (that is, in the contribution of each sector to total intensity) accounted for by changes in the value added share experienced by every branch in the period. It can be interpreted as the impact on total intensity that is attributed by the shift in the value added contribution of the branch if its intensity would have remained unchanged in the period. The intensity effect is reciprocal to that reported by WEA, and represents the impact that changes in intensity of an individual branch would have had on total intensity had its value share remained constant. Finally, the mixed effect is the accumulation of shifts in energy intensity and changes in value share. This allows us to examine changes for specific industrial branches at the three- digit level. We are well aware that changes at the three-digit level can be driven by further compositional changes within three-digit classifications, a subject that we discuss later. 
Although technological improvements are the most optimal from an efficiency sense, it is important to measure the extent to which structural change affects overall levels of intensity as well. This is crucial because it reveals that changes in aggregated intensity cannot be regarded as a direct result of efficiency improvements due to technical change. Aggregated changes in intensity are also explained by changes in the product mix, in the structure of production, and by a combination of both. As we will show, the reduction in energy intensity for the sector in this period is explained to a very large extent by changes in the relative shares of production within particular sectors.

We applied this analysis to the Mexican manufacturing sector. The last column of Table 2 shows a total reduction in industrial energy intensity between 1988 and 1998 of 652.8 megajoules per unit of manufacturing output. Looking at the first row and column in Table 3, if no changes in "technology" had taken place, the change in energy use due to composition of value added would have been reduced by 267.3 megajoules per unit of output. Without changes, the value added structure (that is, if all industries would have grown at exactly the same rate) improvements in internal efficiency in all industries would have been responsible for a 378.7 megajoules reduction in energy intensity. These figures are explained in percentage terms in the fourth column. In these scenarios, almost 41 percent of the changes in industrial energy intensity would have been due to compositional change. In other words, the decline in energy intensive industries was relative to intensive ones. Looking at the next column, 58 percent of the change was due to "technological change". Again, since these figures are presented at the three-digit level, it is important to note that further compositional change could be occurring at levels beyond three digits - a subject we will come to shortly. The calculated residual is in column 3 , and is about 7 megajoules per unit of output. In percentage terms, the residual only explains $1 \%$ of intensity change. This exercise is done for each industrial branch.

Table 3. Estimating compositional and technology-based changes in industrial energy intensity

\begin{tabular}{|c|c|c|c|c|c|c|}
\hline Industry & $\begin{array}{l}\text { Composition effect } \\
\text { (petajoules } p\end{array}$ & $\begin{array}{c}\begin{array}{c}\text { Technology } \\
\text { effect }\end{array} \\
\text { per } \$ 10001993 \text { pes }\end{array}$ & $\begin{array}{l}\text { mixed effect } \\
\text { sos) }\end{array}$ & $\begin{array}{c}\text { Composition } \\
\text { effect } \\
\text { (percenta }\end{array}$ & $\begin{array}{l}\text { Technology } \\
\text { effect } \\
\text { ge of change in int }\end{array}$ & $\begin{array}{l}\text { mixed effect } \\
\text { tensity) }\end{array}$ \\
\hline Iron and steel & 171.5 & -328.3 & -62.1 & -78.4 & 150.0 & 28.4 \\
\hline Chemistry & 5.0 & -22.9 & -0.3 & -27.3 & 125.8 & 1.5 \\
\hline Sugar & -43.0 & -99.1 & 8.3 & 32.2 & 74.0 & -6.2 \\
\hline Petrochemicals (Pemex) & -317.7 & -166.1 & 64.3 & 75.7 & 39.6 & -15.3 \\
\hline Cement & -59.5 & -48.3 & 7.4 & 59.2 & 48.1 & -7.4 \\
\hline Pulp and paper & 4.1 & -68.0 & -1.4 & -6.3 & 104.1 & 2.2 \\
\hline
\end{tabular}

Source: National Accounts System, INEGI; Balance Nacional de Energía, Dirección General de Política y Desarrollo Energéticos, Secretaría de Energía. 
The majority of change is due to a technology effect. This energy efficiency improvement can be a result of several factors or combinations: from shifts within the three-digit level of sector to more energy-saving technologies and a higher rate of investment to product specialization and higher energy prices. Perhaps more importantly, a large part of the reductions are also due to a relative decline in energy intensive industries in Mexico. Mixed effects are practically insignificant.

The importance of compositional and technology effects differ by industry. In the petrochemicals and cement industries, compositional effects account for the most of the sectors' contribution to energy intensity. The slowdown in the economic pace of these branches relative to overall manufacturing growth is their main contribution to the reduction of manufacturing energy intensity.

In the other three branches (sugar, iron and steel, and pulp and paper), internal efficiency effects are dominant. In sugar, both effects are positive, meaning that the reduction in its contribution to manufacturing consumption of energy is both a result of its declining share in manufacturing value added and of improvements in efficiency in the sugar industries. The second effect is, nevertheless, more dominant.

In iron and steel, the story is very different. The positive sign in the composition effect in column one reveals that without internal efficiency developments, the weighted intensity of iron and steel should have increased by 171.5 megajoules per unit of manufacturing value added. On the other hand, considering only internal efficiency, its contribution to overall intensity should have decreased by 328.3 megajoules per unit of value added. The real change was a reduction of 218 petajoules per unit of output. This behavior reflects that technology changes are more dominant in this sector.

The case for the pulp and paper industry seems to be the same as for steel, but in a smaller order of magnitude. That behavior (a positive composition effect and a negative efficiency effect) is the mark of deep technological and product mix restructuring changes at branch level.

\section{Composition, Technology, and International Trade: A Sectoral Discussion}

In this final section, we examine these trends on a sector-by-sector level, in addition to examining the aspect of international trade. This analysis of the sectors confirms the more aggregate level findings outlined above. However, we also find that the energy intensive sectors in the Mexican economy are running large trade deficits with countries where the corresponding sector is more energy intensive. Therefore, the net effect of declining energy intensity in Mexico may not be as impressive as one might think. Reductions in the composition of energy 
intensive industry in Mexico are leading to the importation of more energy intensive goods.

\begin{tabular}{|c|c|c|c|c|c|c|c|c|c|c|c|c|c|}
\hline & \multicolumn{3}{|c|}{ \# of Establishments } & \multicolumn{3}{|c|}{ Lahor productivity } & \multicolumn{3}{|c|}{ Capital-lahor ratio } & \multicolumn{4}{|c|}{ Annual growth rates $1988-98$} \\
\hline & 1988 & 1998 & \% change & 1988 & 1993 & 1998 & 1988 & 1993 & 1998 & Productivity & Value added /I & Employment & $\begin{array}{c}\text { Capital-labor } \\
\text { ratio }\end{array}$ \\
\hline Manufacturing & 138,835 & 361,579 & 160 & 57 & 61 & 53 & 99 & 81 & 87 & 0.8 & 4.3 & 4.8 & 1.3 \\
\hline Sugar & 120 & 238 & 98 & 41 & 65 & 60 & 73 & 114 & 208 & 4 & 3.4 & 0.2 & 11 \\
\hline Pulp and paper & 736 & 2,866 & 289 & 56 & 66 & 72 & 155 & 224 & 212 & 2.6 & 4.5 & 4 & 3.2 \\
\hline Petrochemicals & 15 & 44 & 193 & 86 & 331 & 134 & 1,021 & 795 & 748 & 4.6 & -0.7 & 0.1 & 3.1 \\
\hline Cement & 5,011 & 10,907 & 118 & 27 & 36 & 33 & 296 & 264 & 383 & 2.2 & 2.6 & 4 & 2.6 \\
\hline Iron and steel & 575 & 375 & -35 & 44 & 119 & 248 & 468 & 631 & 846 & 18.9 & 6.1 & 8 & 6.1 \\
\hline
\end{tabular}

Source: Industrial Census, INEGI, several years.

Notes: Value added data comes from National Account System INEGI, 2000.

\section{a) Compositional change}

\section{Petrochemicals}

The information related to petrochemicals in the "Balance de Energía" comprehends only the public-owned PEMEX division of that industry. Private share of the industry is not precisely marginal, but still small (around 20\% of output). The annual growth rate of value added in this branch for the 1988-1998 period was -0.7 , which means an absolute contraction of $6.6 \%$ of output. Given its high-energy intensity, any reduction in value added in this branch has powerful impacts on overall intensity. Technological improvements should have a strong result for the same reason.

Despite the powerful advantage of being an oil producer country, and the related presence of vertical integration economies, state-owned Mexican petrochemicals are experiencing a strong investment crisis, derived from the deep financial dependency of the Mexican government on Oil fiscal revenues. Over the last 5 years, taxes charged to PEMEX as a whole represent $30 \%$ of all fiscal revenues. State expenditure control is one of the hardest lines in the new macroeconomic conduction of the Mexican economy, but at the same time, huge debt service outflows exert tremendous pressure on fiscal revenues. Capital investment in this industry has therefore been cut because of fiscal needs, making it impossible to face even capital reposition. The capitallabor ratio between 1988 and 1998 decreased severely at a $3 \%$ annual rate. A reduction of $20 \%$ in absolute intensity 
in the period highlights, nevertheless, footprints of internal efficiency effects on energy intensity in the industry, reflecting maybe product mix changes at a higher level of disaggregation.

\section{Cement}

The cement industry (a market dominated in Mexico by two big companies) impact on intensity reduction is explained by its lower growth rate, 2.6\% annually. This has been the usual rate of growth in this industry since 1980, given its relation to infrastructure (rather stagnated because of fiscal austerity) and population growth.

Although this performance doesn't mean a real contraction, its share of manufacturing value added decreased from 15 to $13 \%$.

Given its high consumption of heavy oil derivatives (combustóleo represents $75 \%$ of the energy consumed in the period, constant percentage), it is also one of the most energy intensive industries. A $12 \%$ reduction in absolute energy intensity in cement is therefore not a minor change. Capital labor ratios in cement show a small but constant technical escalation (2.6\% of annual rate in the period). There is no sign of changes in fuel mix, and since core technology hasn't change radically, intensity reduction must come from incremental technical changes, energy waste reduction, and age related efficiency (number of establishments doubled in the period).

\section{b) Technological change?}

As we discussed earlier, given data limitations, the efficiency changes only measure energy intensity at the three-digit level for these energy intensive industries. For that reason, our analysis cannot pick up further compositional changes that may be occurring within each of these sectors. That being said, of the five industries, there is evidence of real technological changes in at least two of the sectors, iron and steel and pulp and paper.

Iron and Steel

The iron and steel industry, particularly steel, is the clearest and most documented example of technological change that has led to decreases in energy use of these five sectors. As shown in Table 4, Mexican iron and steel shut down 35 percent of its older, inefficient plants and upgraded many more. As a result, they enjoyed an 18 percent increase in productivity, and a 7 percent increase in output. Its capital intensity also rose by five times the average for Mexican manufacturing.

The Mexican steel sector underwent a massive restructuring in the late 1980s that contributed to gains in energy intensity. In 1988, Mexico restructured its steel 
market, privatizing the largest state-owned company, eliminating protections for many private steel companies, and relaxing rules for foreign investment. In support of these changes the World Bank issued a 400 million dollar loan that included 150 billion dollars for technological modernization (Gentry, 1998).

By 1992, Mexico was no longer operating open hearth furnaces. Electric arc furnaces became the dominant steel technology by 1998, producing 65 percent of Mexican steel production in metric tons (CANACERO, 2000). Not only are electric arc furnaces relatively much less energy intensive to begin with, industrial prices of electricity doubled during this period, triggering the steel sector to use less electricity. Domestically developed processes by HYLSA (HYLI and HYLII) were designed specifically to meet energy saving goals. Efficiency savings are also related to an increased use of continuous casting (against top puring) which covered already $85 \%$ of production and a more extended use of coke oven gas and blast furnace gas (Comission for Environmental Cooperation, 2001). As a result of these transformations, physical intensity decreased from 25.5 to 17.5 giga joules per ton of steel from 1989 to 1997.

Pulp and Paper

Whereas most of the gains in energy intensity in the iron and steel sector came from closing old plants and modernizing others, energy intensity in pulp and paper was a function of installing a large number of new plants that utilized more efficient technologies and fuels.

Energy use is often a function of plant vintage. As shown in Table 4, the number of establishments in the pulp and paper sector almost quadrupled between 1988 and 1998. In addition to these newer vintages, these new plants used sources of energy that are much more energy efficient. Much of the older pulp and paper establishments were fueled by combustoleos, considered to be one of the least energy efficient fuels in Mexico. Many of the newer plants use a larger share of electricity and natural gas (Secretaria de Energia, 2000).

\section{Sugar}

The sugar industry is for several reasons an exception. It is the only agroindustry that is not a heavy industrial branch, and the only one in the set with a biomass energy base ( $68 \%$ of its energy consumption comes from burning cane). Thirty percent of its reduction in weighted intensity was explained by its reduced share of manufacturing value added, while $74 \%$ was explained by internal efficiency change. This indicates that technological changes should have had impacts in the industry's energy use.

The sugar industry has experienced a long term decay since the begining of the 1970's, basically due to a rentability crash. The state responded to the increasing 
demand by investing heavily in the sector in the second half of the 1970's; by 1980 state's participation was $76 \%$ of total production. A period of stagnation and increased import dependencey followed the 1982 crisis, which ended with the privatization of all state owned "ingenios" between 1988 and 1989. The increase in units between 1988 and 1998 is more clearly understood as a return to activity of some of the numerous "ingenios" that were paralized after 1982. Privatization and consequent recapitalization occurred in an environment of excess capacity (the main reason of the current commercial dispute with US trade barriers and fructose imports; by 2000, Mexico's excess production rounded the 600,000 tons of sugar).

The initial year of our period of analysis was one of structural transition and historically low levels of production. Energy intensity rose slowly until 1990, and dropped from then onwards. There is some evidence of specific energy saving programs for the sugar industry (see for example, the ONUDI - IPN program for cleaner sugar production practices), which, nevertheless, started only after 1993 when the diminishing trend was already visible. Investment in machinery and equipment remained stagnated along the period, evidencing no significant vintage replacement. In our view, the reduction of energy intensity is mainly explained by a static improvement in efficiency, resulting mainly from a better use of installed capacity, complemented by improvements in the quality of sugar cane. By 2000, the industry entered a deep crisis (provoked both by the sudden rise in fructose imports and by a falling international price), and the government expropriated 27 of the main "ingenios." The medium and long term effects of these developments are still unclear, but energy-use improvement in this branch will depend, of course, on its economic recovery and technolo gical upgrading.

\section{c) Trade effects}

What dampens some of the impressive findings discussed earlier in the paper is that Mexico's compositional shift toward less energy intensive industry has resulted in the importation of energy intensive goods from countries where the corresponding sector is more energy intensive than the sector is in Mexico.

As shown in Table 5, there is little doubt that Mexican industrial trade has shifted to energy intensive imports. Taken as whole, the five most significant industries for intensity reduction had increasing trade imbalances of 1.5 billion US dollars in 1990, to 5.7 in 1998, and 8.9 in 2000. At the two-digit level, the import/GDP coefficient doubled, between 1988 and 1994 from 30 to $66 \%$ in paper and printing industries, from 36 to $75 \%$ in chemicals and from 47 to $86 \%$ in basic metals. Although those figures reduced in 1995 due to the trade impacts of a 100\% devaluation of the Mexican peso (in the middle of the worst economic crisis in the country since 1982), import coefficients were launched again after the recession, growing faster than output. 


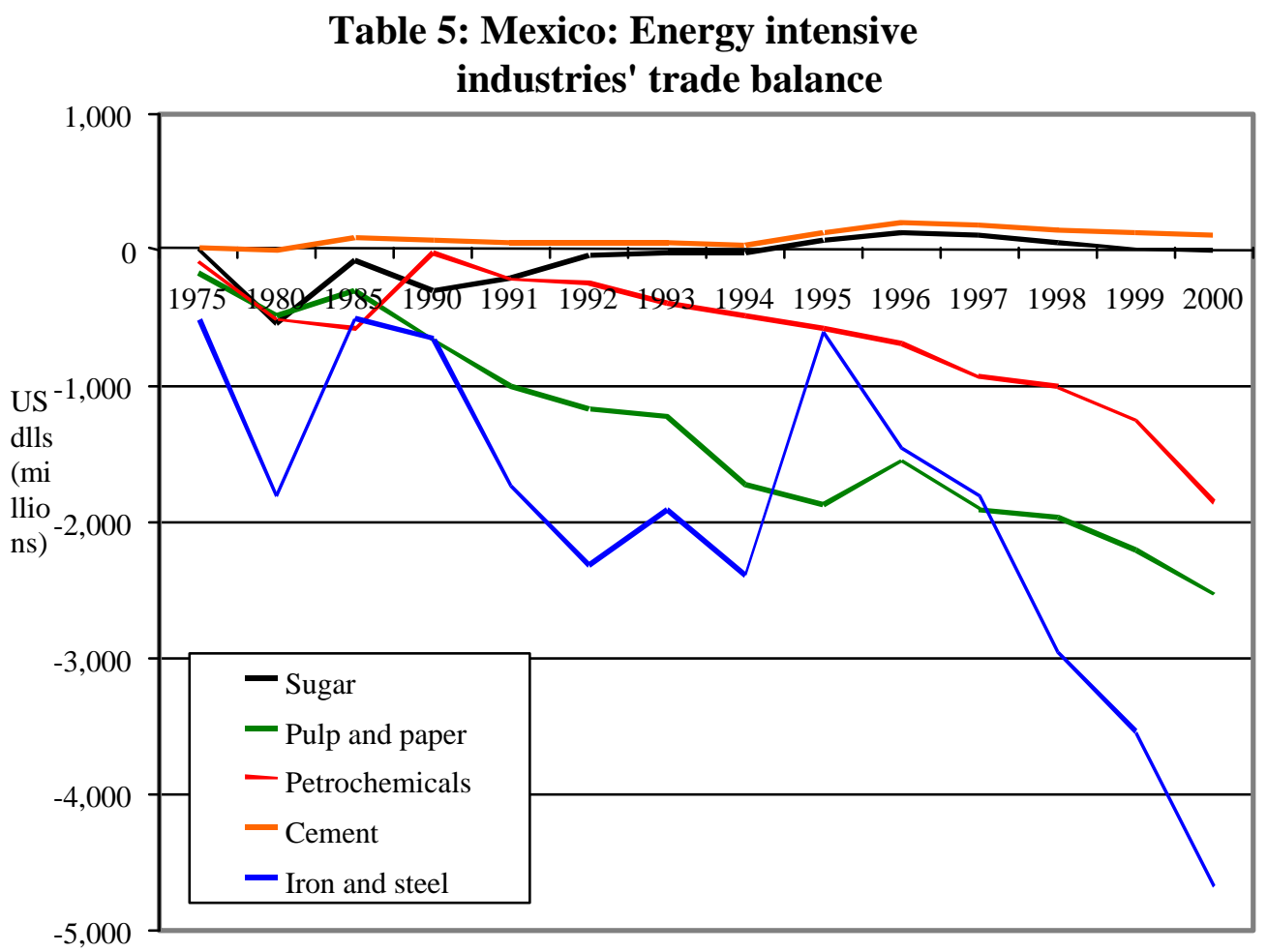

Source: Estadísticas del Comercio exterior, INEGI, several years.

Trade in sugar and cement is not significant. In sugar trade only takes place to balance internal consumption. Therefore, trade balance in this industry is determined by small fluctuations in production volume. Export volumes are reduced to production surplus and imports growth explained by bad production years. As noted, the growing production surplus of the last years faces strong trade barriers in the US market. Trade in cement is restrained to specialized products and to border regions, and the industry shows very small trade surpluses.

On the other hand, imports are important in pulp and paper, petrochemicals, and iron and steel. Mexico has historically run deficits in these industries. Growing deficits were the norm in the seventies. In the eighties, trade imbalance was slightly reduced in petrochemicals. In the nineties, however, trade deficits expanded at great speed. Imports' annual average rates between 1990-2000 reach $23.8 \%, 12 \%$ and $26 \%$ in pulp and paper, petrochemicals and steel, respectively. Despite growing exports, the steel industry shows growing trade imbalances due to higher value added in imports. 
All three industries that are running large and growing trade deficits-pulp and paper, iron and steel, and petrochemicals-are less energy intensive in Mexico than in the U.S., the major exporter of these goods to Mexico. This is stark in Table 6.

\section{Table 6:}

\begin{tabular}{|lrr|}
\hline Energy Intensity in Mexico and the U.S. \\
Sector & \multicolumn{3}{c|}{ Energy Intensity (MJ/\$) } \\
& & \\
& Mexico & U.S. \\
Pulp and Paper & 37.45 & 40.36 \\
Iron and Steel & 101.48 & 118.79 \\
Petrochemicals & 19.63 & 23.77 \\
\hline
\end{tabular}

Source: National Energy Balance (Mexico), Survey of Manufactures (US)

In each case, Mexican industry is slightly less energy intensive than in the U.S. Much of this is due to plant vintage and energy subsidies in the U.S.

\section{Conclusions and the Need for More Research}

This paper has analyzed the energy intensity of Mexican manufacturing from 1988 to 1998 , a period of significant decline in such intensity. Using standard methods we found that the reduction in energy intensity in the Mexican economy is due to both compositional factors and technological changes in the most energy intensive industries.

Some of the technological factors are indeed impressive. In the pulp and paper and steel industries, we showed that they have benefited from the installation of new core technologies and energy combusting facilities, in addition to closing a number of older, less energy efficient plants. A very strong element in the observed energy efficiency improvement is, nevertheless, the reduced importance of some energy intensive branches, fundamentally petrochemicals. To highlight the importance of composition effects leads necessarily to broader structural issues and economic sustainability considerations.

On one hand, "good" energy reductions are in the medium and long term a result of steady technology replacement of more efficient technologies. The disordered and polarized pattern of growth in Mexican manufacturing in the last decades introduced waves of equipment and plant replacement in export oriented and oligopolic sectors, whereas medium and small enterprises continue to operate with old equipment. The weaknesses of the financial sector and other systemic 
handicaps reinforce an adverse environment for local adaptive innovation and technology absorption.

From a broader, North American perspective, Mexico's energy gains are losses for the United States. We find that those sectors where Mexico's manufacturing is reducing energy intensity are net importers of goods from the United States. For those sectors, U.S. energy intensity is higher than in Mexico. The net result of this tighter market integration is an increase in energy use in the North American economy.

With regards to future research, analysis like the one used in this paper should benefit from plant-level analysis. At the moment, quantitative data does not exist at such a level in Mexico, and information is scattered. Thus, qualitative interviews and plant-level visits could nicely round out the sector level examination we conducted later in the paper.

Francisco Aguayo is an economist at the Program for Science, Technology, and Development at El Colegio de Mexico in Mexico. Kevin Gallagher is a research associate at the Global Development and Environment Institute at Tufts University.

\section{REFERENCES}

CANACERO (2000). Diez Anos De Estadistica Siderugica, 1990-1999. Mexico.

Comission for Environmental Cooperation (2001), Mexico and Emerging Carbon Markets. Investment Opportunities for Small and Medium-size Companies and the Global Climate Agenda, NACEC, Montreal.

Gentry, Bradford (1993). "Mexican Steel." Private Capital Flows and the Environment in Latin America. Edward Elgar.

INEGI (2003) National Accounting System for Mexico. Mexico.

INEGI, (2000), Estadísticas del Comercio Exterior, Banco de Información Económica, Mexico.

INEGI, (1989, 1994, 1999), Censo Industrial, Mexico.

Richardson, Harry Ward (1978), Regional and Urban Economics, Harmondsworth, Penguin.

Secretaría de Energía (2000), Balance Nacional de Energía 1999, México. 
Sinton, Jonathan, and David Fridley (2000). "What Goes Up? Recent Trends in China's Energy Consumption." Energy Policy, March.

Sterner, Thomas (1985). "Structural Change and Technology Choice: Energy Use in Mexican Manufacturing Industry, 1970-1981. Energy Economics, November.

Sterner, Thomas (1989). "Factor Demand and Substitution in a Developing Country: Energy Use in Mexican Manufacturing." Scandinavian Journal of Economics 91(4), 723-739.

Sterner, Thomas (1990). "Energy Efficiency and Capital Embodied Technical Change: The Case of Mexican Cement Manufacturing." Energy Journal, 11, 2.

ONUDI (2003). http://www.cmpl.ipn.mx/Area_Tecnica/Azucar.htm. United Nations Development Program (UNDP), (2001). World Energy Assessment: Geneva.

United States Census Bureau, (2002). Annual Survey of Manufactures. Washington. 
The Global Development And Environment Institute (G-DAE) is a research institute at Tufts University dedicated to promoting a better understanding of how societies can pursue their economic goals in an environmentally and socially sustainable manner. G-DAE pursues its mission through original

research, policy work, publication projects, curriculum development, conferences, and other activities. The "G-DAE Working Papers" series presents substantive work-in-progress by G-DAE-affiliated researchers. We welcome your comments, either by e-mail directly to the author or to G-DAE, Cabot Center, Fletcher School, Tufts University, Medford, MA 02155 USA; tel: 617-627-3530; fax: 617-627-2409; e-mail: gdae@tufts.edu; web: http://ase.tufts.edu/gdae.

\section{Papers in this Series:}

00-01 Still Dead After All These Years: Interpreting the Failure of General Equilibrium Theory (Frank Ackerman, November 1999)

00-02 Economics in Context: The Need for a New Textbook (Neva R. Goodwin, Oleg I. Ananyin, Frank Ackerman and Thomas E. Weisskopf, February 1997)

00-03 Trade Liberalization and Pollution Intensive Industries in Developing Countries: A Partial Equilibrium Approach (Kevin Gallagher and Frank Ackerman, January 2000)

00-04 Basic Principles of Sustainable Development (Jonathan M. Harris, June 2000)

00-05 Getting the Prices Wrong: The Limits of Market-Based Environmental Policy (Frank Ackerman and Kevin Gallagher, September 2000)

00-06 Telling Other Stories: Heterodox Critiques of Neoclassical Micro Principles Texts (Steve Cohn, August 2000)

00-07 Trade Liberalization and Industrial Pollution in Mexico: Lessons for the FTAA (Kevin Gallagher, October 2000) (Paper withdrawn-see www.ase.tufts.edu/gdae/ for details)

00-08 Waste in the Inner City: Asset or Assault? (Frank Ackerman and Sumreen Mirza, June 2000)

01-01 Civil Economy and Civilized Economics: Essentials for Sustainable Development (Neva Goodwin, January 2001)

01-02 Mixed Signals: Market Incentives, Recycling and the Price Spike of 1995. (Frank Ackerman and Kevin Gallagher, January 2001) 
01-03 Community Control in a Global Economy: Lessons from Mexico's Economic Integration Process (Tim Wise and Eliza Waters, February 2001)

01-04 Agriculture in a Global Perspective (Jonathan M. Harris, March 2001)

01-05 Better Principles: New Approaches to Teaching Introductory Economics (Neva R. Goodwin and Jonathan M. Harris, March 2001)

01-06 The \$6.1 Million Question (Frank Ackerman and Lisa Heinzerling, April 2002)

01-07 Dirt is in the Eye of the Beholder: The World Bank Air Pollution Intensities for Mexico (Francisco Aguayo, Kevin P. Gallagher, and Ana Citlalic González, July 2001)

01-08 Is NACEC a Model Trade and Environment Ins titution? Lessons from Mexican Industry (Kevin P. Gallagher, October 2001)

01-09 Macroeconomic Policy and Sustainability (Jonathan M. Harris, July 2001)

02-01 Economic Analysis in Environmental Reviews of Trade Agreements: Assessing the North American Experience. (Kevin Gallagher, Frank Ackerman, Luke Ney, April 2002)

03-01 Read My Lips: More New Tax Cuts-The Distributional Impacts of Repealing Dividend Taxation (Brian Roach, February 2003)

03-02 Macroeconomics for the $21^{\text {st }}$ Century (Neva R. Goodwin, February 2003)

03-03 Reconciling Growth and the Environment (Jonathan M. Harris and Neva R. Goodwin, March 2003)

03-04 Current Economic Conditions in Myanmar and Options for Sustainable Growth (David Dapice, May 2003)

03-05 Economic Reform, Energy, and Development: The Case of Mexican Manufacturing (Francisco Aguayo and Kevin P. Gallagher, July 2003) 